
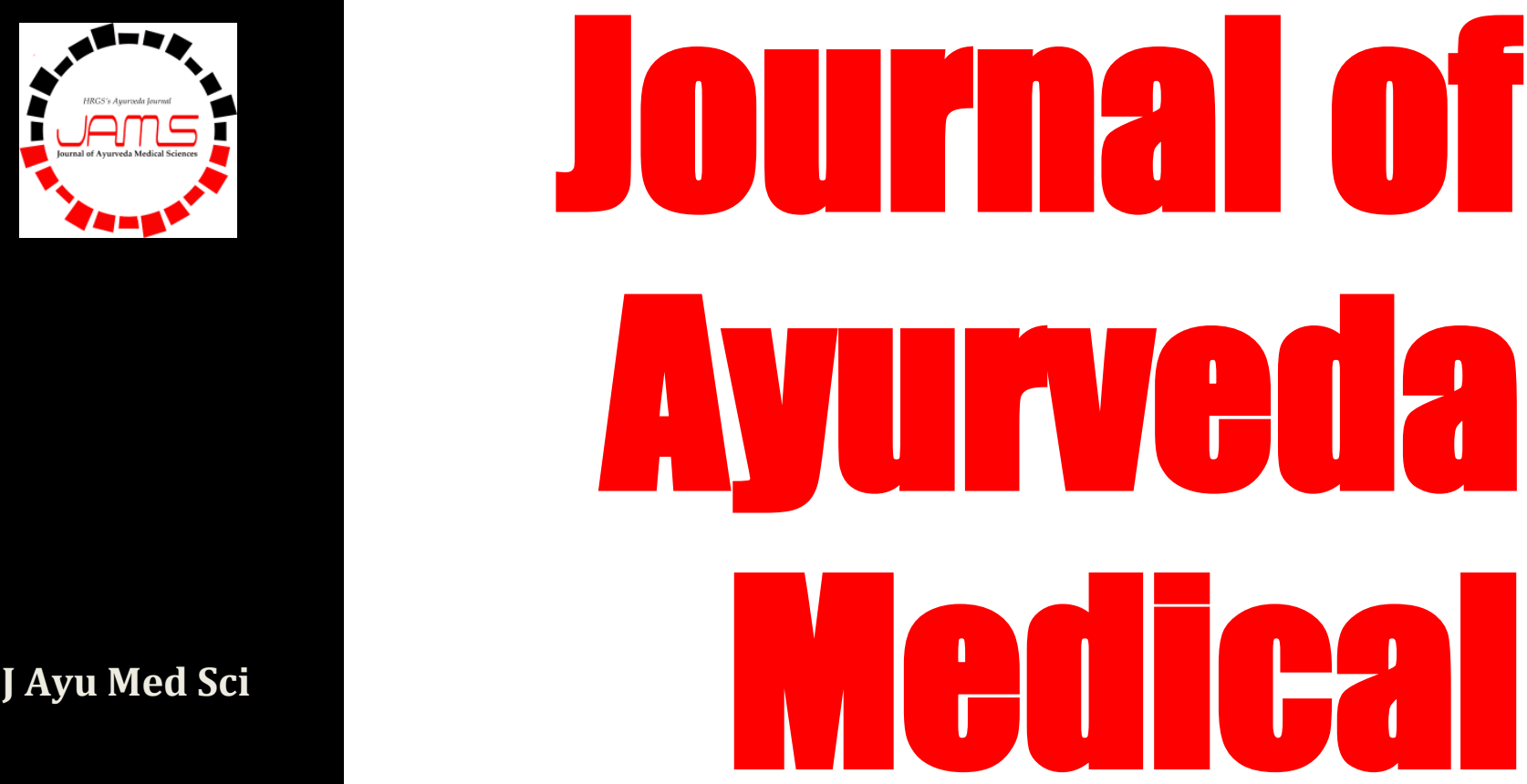

J Ayu Med Sci

Quarterly Journal for Rapid

Publication

of Researches

in Ayurveda

and Other Traditional

Medicines

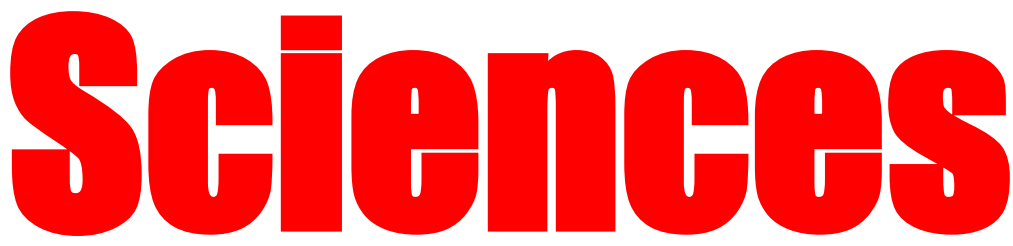

ISSN 2456-4990

\title{
Macro-microscopic characterization of the Punica granatum L. flower
}

Punica granatum L. flowers called as Matulampoo in Siddha is a highly medicinal raw material used for the treatment of eye diseases, asthma, diabetes and diarohea. A study dealt with the morphology, anatomy and powder microscopy of P.granatum dried flowers revealed that the drug consists of bisexual and male flowers. The dried flower is dark red in colour, thick and leathery. Powdered flower drug is creamish white in colour with characteristic smell and taste. The microscopic features recorded from the study will help in authentication of this medicinal material with parameters employed in pharmacopoeial quality control.

Divya et al. 


\section{Macro-microscopic characterization of the Punica granatum L. flower}

Divya Kallingilkalathil Gopi, Rubeena Mattummal, Remya Andalil, Erni Bobbili, Brindha Sundaramoorthy, Sunil Kumar Koppala Narayana*, Sathiya Rajeshwaran Parameswaran ${ }^{1}$

Department of Pharmacognosy, ${ }^{1}$ Assistant Director and In charge, Siddha Central Research Institute, Central Council for Research in Siddha, Ministry of AYUSH, Govt. of India, Arumbakkam, Chennai, Tamil Nadu, India 600106.

\section{ABSTRACT}

Introduction: Dried flowers of Punica granatum L. constitute the drug Matulam poo which is widely used in both traditional and modern medicine. In Siddha it is used for the treatment of diabetes and gastro intestinal diseases. The present study deals with detailed pharmacognosy including morphological, anatomical, quantitative and powder microscopic characterization of this floral drug. Methods: Dried authenticated floral drug was collected from SMPG Mettur and subjected to macro-microscopic screening. Results: Anatomical study of the sepal showed presence of numerous rosette crystals towards the lower epidermis. Quantitative study revealed the presence of anomocytic stomata in the outer region of sepal. Some of the distinguishing characters observed in the powder microscopy were abundant corolla fragments with anomocytic stomata, epidermal cells with striations, long fibers, calcium oxalate crystals and spherical pollen grains. The current study offers a detailed pharmacognostic profiling of this important floral drug in view of its macromicroscopy.

\section{KEYWORDS}

Matulam, Quantitative microscopy, Rosette crystals

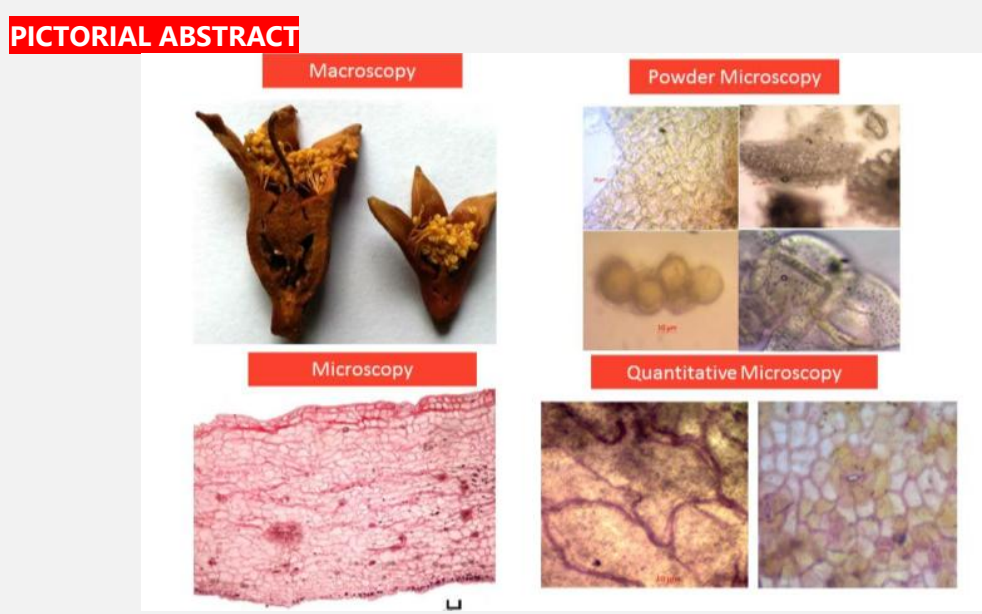

ARTICLE HISTORY Received 26.06.2018 Accepted 17.07.2018

CORRESPONDENCE Dr KN Sunil Kumar, Research Officer and HOD (Pharmacognosy), Siddha Central Research Institute, CCRS (Ministry of AYUSH, Govt. of India), Arumbakkam, Chennai, Tamil Nadu, 600 106, India. Email: kn.sunil@gov.in

CITE THIS RESEARCH AS Divya KG, Rubeena M, Remya A, Erni B, Brindha S, Sunil Kumar $\mathrm{KN}$, Sathiya Rajeswaran P. Macro - microscopic characterization of the Punica granatum flower. J Ayu Med Sci 2018;3(2):384-9.

DOI 10.5530/jams.2018.3.12

Indian tradition has immense plant based knowledge on health care. Considered to be symbol of fecundity Pomegranate whose fruit rinds, bark, flowers and roots are used worldwide as taenicides, owing to alkaloids and for the treatment of diarrhea and oral and genital lesions, owing to the presence of tannins and astringency. ${ }^{[1]}$ The name pomegranate comes from the Latin Pomum meaning apple and granatus meaning full of seeds. Punica granatum L. is known as apple punice from Lytharaceae family (previously Punicaceae). Native to central Asia, it is highly adaptive to a wide range of climates and soil conditions and is cultivated along the Mediterranean basin, Asia, and the United States. ${ }^{[2]}$

The tree/fruit consist of several components as: seed, juice, peel, leaf, flower, bark, and roots, each of which exerts intriguing pharmacologic activity ${ }^{[3]} P$. granatum has been used widely in traditional medicine for treatment of diarrhea, dysentery, acidosis, helminthiasis, hemorrhage and urinary disorders such as kidney stone, bleeding of kidney, irritable condition of bladder inflammation, painful urination, burning sensation, problem in urine discharge ${ }^{[4]} P$. granatum is considered as a diet in convalescence after diarrhea. ${ }^{[5,6]}$ It is used in Siddha, Ayurveda and Unani medicine especially for the treatment of gastro-intestinal diseases. The rind of the fruit and flowers, combined with aromatics, such as cloves, cinnamon, coriander, pepper is given as bowel astringent in diarrhea, dysentry and gastralgia. ${ }^{[7,8]}$ Pulp is a good anti-diarrhoeal agent. ${ }^{[9,10]}$ The extract of $P$. granatum significantly increased the rate of wound contraction and turnover of collagen which is the major component strengthening and supporting the extracellular tissues. $^{[11]}$

In Ayurvedic medicine the pomegranate is considered a pharmacy unto itself and is used as an antiparasitic agent, a blood tonic, and to heal aphthae, diarrhea, and ulcers. ${ }^{[12]}$ In Siddha 
flower of $P$. granatum is used in the preparation of Makaelatikulikai used for the treatment of eye diseases, emesis, diabetes and renal calculus and Makavacantakucumakaram used for treating asthma, tuberculosis, inflammation, fever, diarohea, stomach pain and anuria. ${ }^{[13]}$

\section{Plant material}

Botanically authenticated dried flowers of $P$. granatum were procured from Siddha Medicinal Plants Garden (SMPG-CCRS), Mettur, Tamil Nadu.

\section{Macroscopy}

Macroscopy was documented by Nikon COOLPIX5400 digital camera. The longitudinal sections of male and hermaphrodite flowers were taken and photographed using Zeiss V8 Stereomicroscope.

\section{Microscoppy}

Part of the flower sample was preserved in FAA (Formalin-5ml + Acetic acid-5ml $+70 \%$ Ethyl alcohol-90ml) for sectioning .Transverse sections of the preserved specimens were hand cut using a 7'o clock platinum blade, stained with safranine and photographed using Nikon ECLIPSE E200 trinocular microscope attached with Nikon COOLPIX5400 digital camera under bright field light .Magnifications were indicated by the scale-bars.

4. Quantitative microscopy

Quantitative microscopy of sepal was done boiling about 5 minutes with $10 \% \mathrm{KOH}$ solution followed by maceration and staining with safranine.

\section{Powder microscopy}

The dried sample was powdered using autoclaved pestle and mortar was powdered, passed through mesh no. 60, and preserved in an air-tight covers for powder microscopy. A pinch of powder was mounted in glycerine on a clean microscopic slide. Slides were observed under Nikon ECLIPSE E200 trinocular microscope and diagnostic characters were identified. Individual characters were magnified to $400 \mathrm{X}$ and photographed.

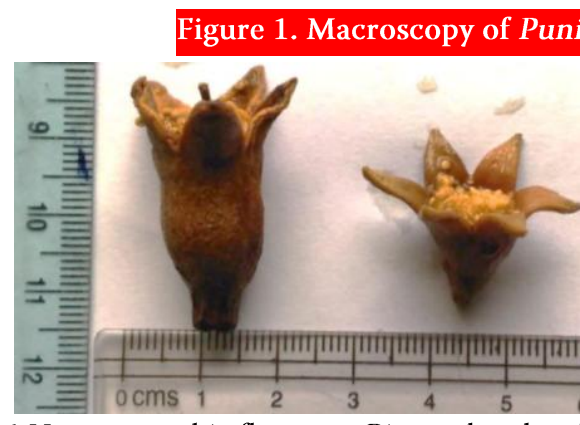

1.1 Heteromorphic flowers - Bisexual and male

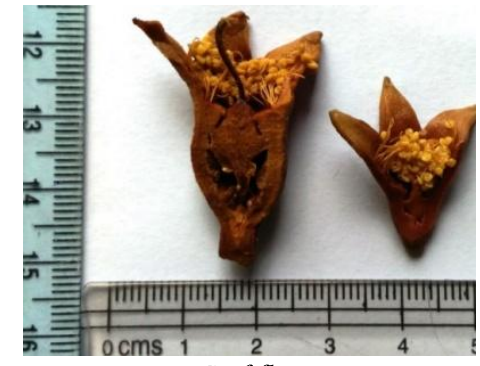

1.2 LS of flowers

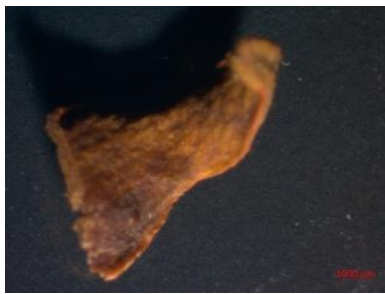

2.1 Sepal outer and inner surface

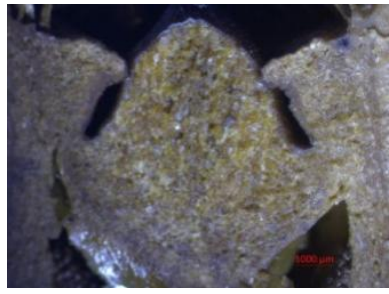

2.4. Stylopodium
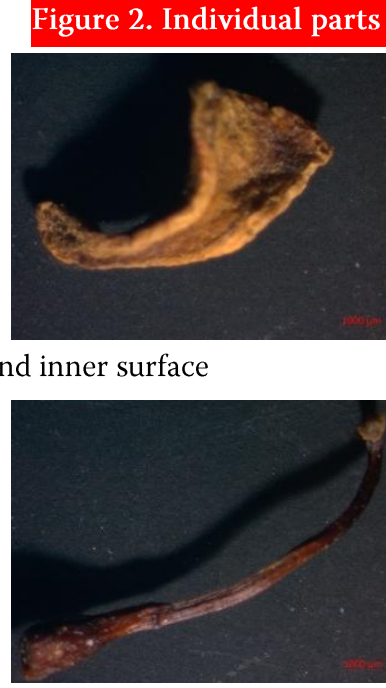

2.6 Style and stigma

The drug consists of dried bisexual and male flowers of P. granatum. Bisexual flowers are vase shaped and have wellformed stigma, style and ovary representing the female parts and filaments and anthers representing the male part; male flowers are

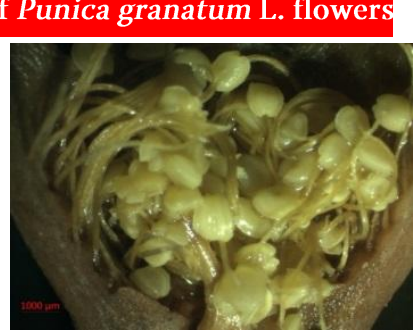

2.2 Androecium

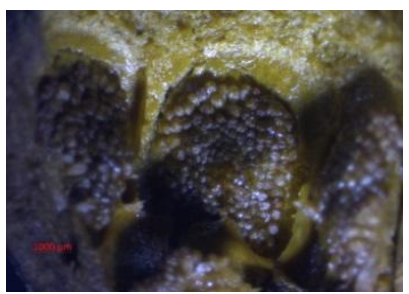

2.7 Gynoecium with ferile ovules

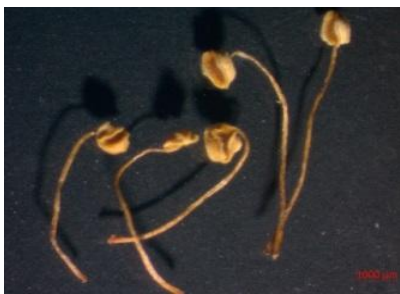

2.3 Anthers

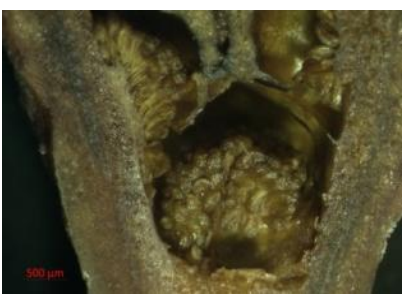

2.8 Rudimentary Ovules from male flower

smaller in size and have only well-developed male parts; the bisexual flower measured 2.5 to $4.2 \mathrm{~cm} 1$ and $0.8 \mathrm{~cm}$ to $2.6 \mathrm{~cm}$ diameter while the male flowers measures 1.4 to $2 \mathrm{~cm}$ in length and 0.6 to $0.8 \mathrm{~cm}$ in diameter (Fig 1 ). 
The calyx is red, thick, and leathery fused at the base, and usually pentamerous, although infrequently tetramerous forming the crown of mature fruit; ovary inferior, and the numerous stamens comprising of yellow anthers attached to long red filaments, which are inserted on the inner surface of the calyx tube (Fig 1); anthers surround the elongated style, which at the base broadens into a conical-shaped stylopodium (Fig 2); anthers dithecous and dehisces longitudinally along the median part of the anthers; filament of the stamen is circular in outline; pollen grains spheroidal, tricolpate with a smooth exine and measured about 20 to 21 micrometer in diameter.
The numerous anatropus ovules are seen attached to swollen fleshy parietal placental tissue; the two flower types can be readily distinguished based on differences in pistil development; bisexual flowers possess a well-developed pistil with an elongated style that extends at or above the height of anthers; flowers have a prominent U-shaped ovary containing numerous elliptical ovules. Male flowers have a style that is shorter than the height of anthers and an ovary which is V-shaped; ovules rudimentary, much smaller in size, and have an irregular surface compared with the rounded, cream-colored, and glistening appearance of ovules in bisexual flowers (Fig 2).

Figure 3. TS of Punica granatum L. sepal

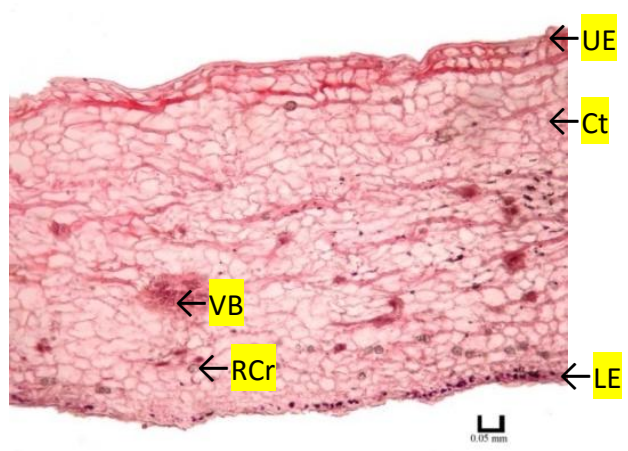

3.1 TS of expanded sepal lobes

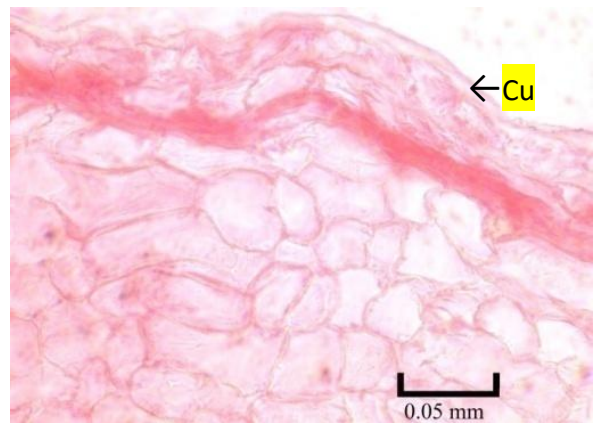

3.3 Upper region

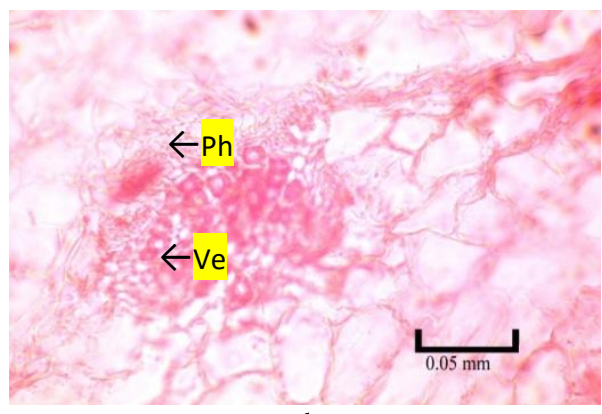

3.5 Vascular region

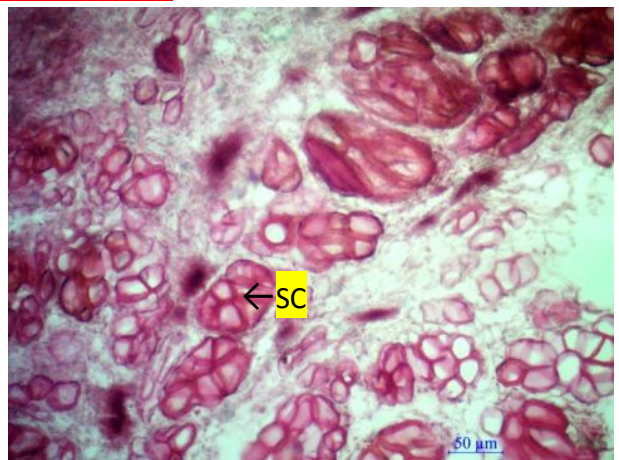

3.2 Outer region of sepal

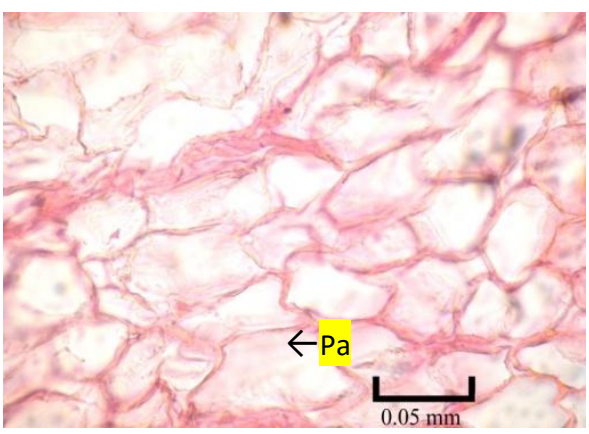

3.4 Middle region

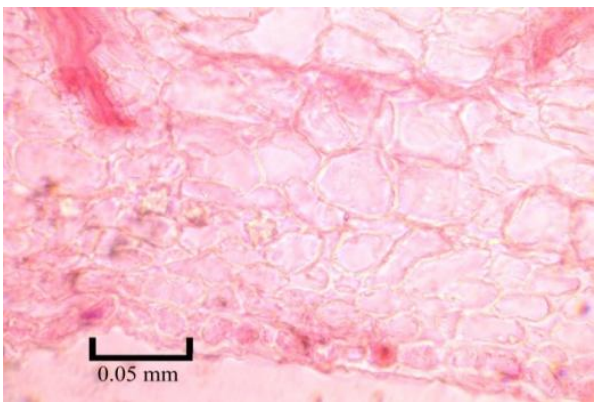

3.6 Lower region

$\mathrm{Cu}$ - cuticle; $\mathrm{Ct}$ - cortex; LE - lower epidermis; $\mathrm{Pa}$ - parenchyma; $\mathrm{Ph}$ - phloem; $\mathrm{RCr}$ - rosette crystals; $\mathrm{SC}$ - stone cells; UE - upper epidermis; VB - vascular bundle; $\mathrm{Xy}$ - xylem

Quantitative microscopic features of the sepal has been recorded for authentication of the drug and the results; the epidermal cells of the inner surface showed the presence of unicellular trichomes and were completely absent in the outer surface the epidermal cell number varied in both the surfaces; anomocytic stomata were present only in outer region of sepal (Table 1 and Fig 4). 


\section{Table 1. Quantitative microscopy of Punica granatum sepa}

\begin{tabular}{l|cc}
\hline Parameters $\left(/ \mathbf{m m}^{2}\right)$ & Outer & Inner \\
\hline Trichomes & - & 54 \\
\hline Epidermal number & $220-240$ & $280-320$ \\
\hline Stomatal number & $10-18$ & - \\
\hline Vein termination number & & 6 \\
\hline Vein-islet number & & 2 \\
\hline
\end{tabular}

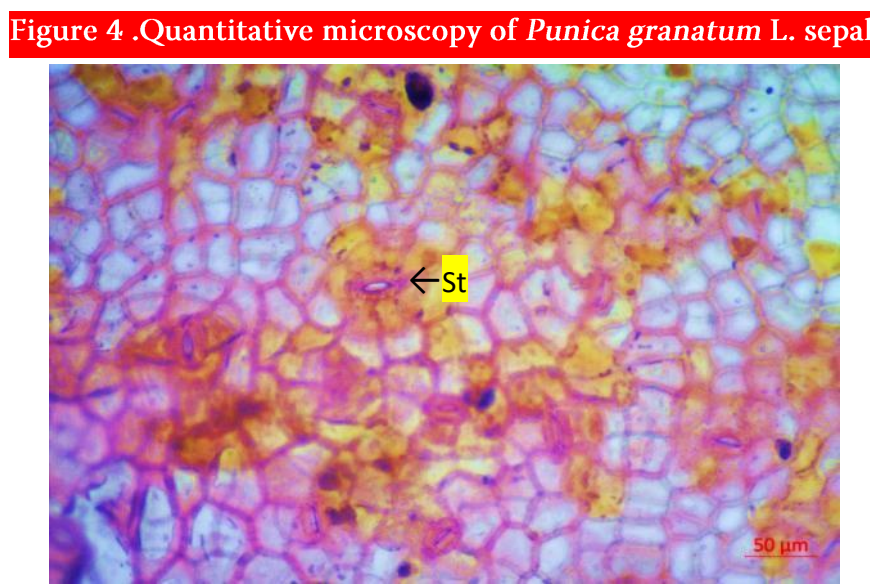

4.1 Epidermal cells with stomata

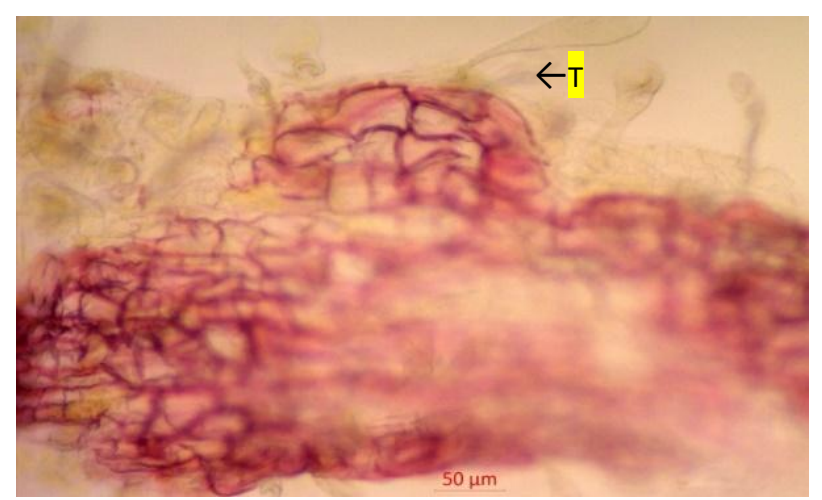

4.2 Epidermal cells with trichomes

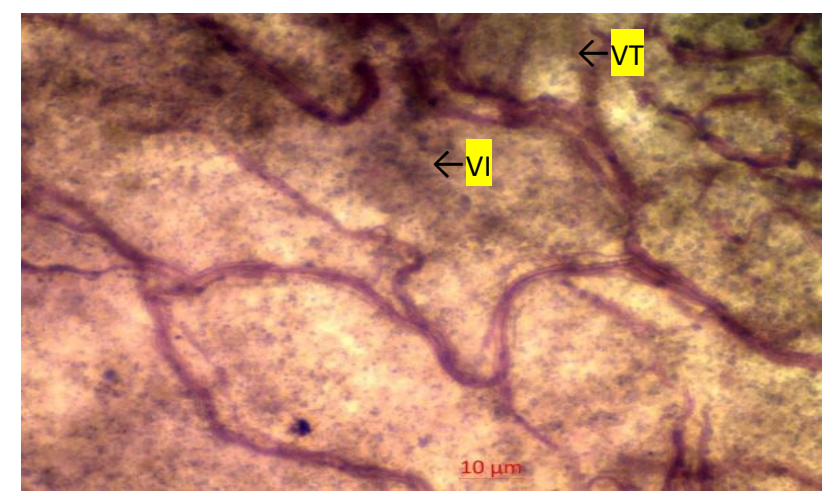

4.3 Vein islets and terminations

St - stomata; T- trichome, VI - vein islet, VT- vein termination

Powdered flower drug showed presence of abundant corolla fragments made of parenchyma cells, thin walled irregularly outlined epidermal cells with striations, trichomes, thick walled parenchyma cells, anomocytic stomata, mesophyll cells of sepal, annular vessels, long fibres, calcium oxalate crystals of both rosette and prismatic type, spherical pollen grains and heteromorphic stone cells (Fig 5).

Punica granatum belongs to the monotypic genus which comprises of only two species namely Punica granatum and Proto punica granatum. Although previously classified under the family Punicaceae recent morphological, ${ }^{[15]}$ molecular $^{[16]}$ as well as the new classification in the APG IV system ${ }^{[17]}$ suggests that it is instead a member of Lythraceae. Chaudhari and Desai classified pomegranate flowers into three types: male, hermaphroditic, and intermediate. ${ }^{[18]}$ Observations of gradients of flower types collected during the present study recorded the presence of only male and hermaphroditre flowers with abundance of male flowers which can be considered as a way to spread genes, because pollen spread is more efficient with more male flowers as recorded by Herlihy and Eckert, 2002 $2^{[19]}$ as well as Tanurdzic and Banks, $2004 .^{[20]}$

Andromonoecy as well as other fluctuating sexual expression types is proposed to allow a species to optimize the allocation of limited resources to male and female function. ${ }^{[21]} P$. granatum also showed this condition with the presence of both hermaphrodite and functional male flowers on the same plant.

The anatomical studies were in correlation with the studies conducted by Devi et al, 2015 $5^{[22]}$ but differed in the presence of homogenous parenchymatous cortex and comparatively abundance of xylem and phloem. Even though anatomical studies have been carried out earlier this study gives the first hand detailed account of morphology, anatomy, 
quantitative and powder microscopic study of the well-known floral drug with immense antiquity.

Siddha system of medicine makes use of many flower drugs for their medicinal preparations. Pomegranate flowers have been used in all the three traditional system of medicines viz
Siddha, Unani and Ayurveda as a remedy for various disorders. Thus the present study on the morphology, anatomy and powder microscopy of $P$. granatum will aid in the better understanding of this important floral drug.

\section{Figure 5. Powder microscopy of Punica granatum L. flower}

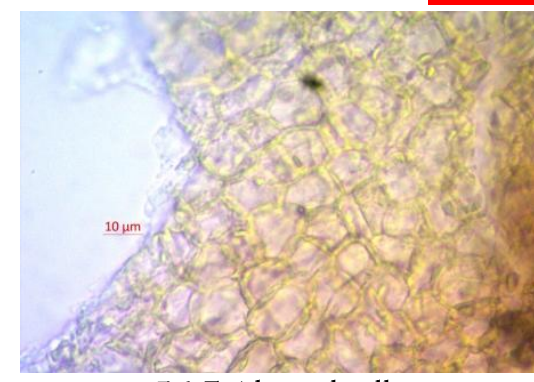

5.1 Epidermal cells

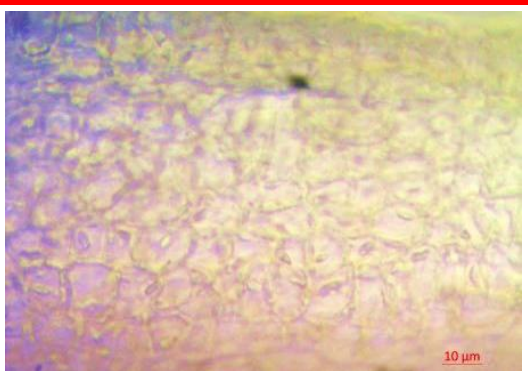

5.2 Epidermal cells with anomocytic stomata

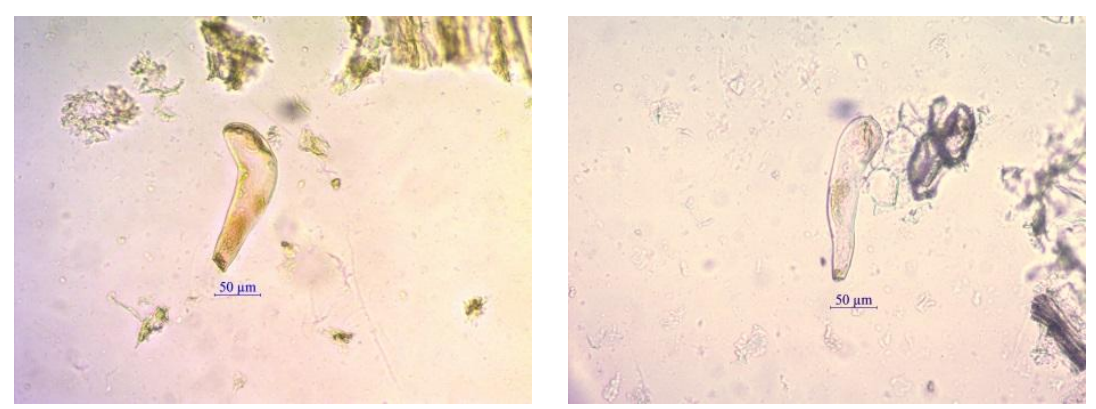

\subsection{Trichomes}
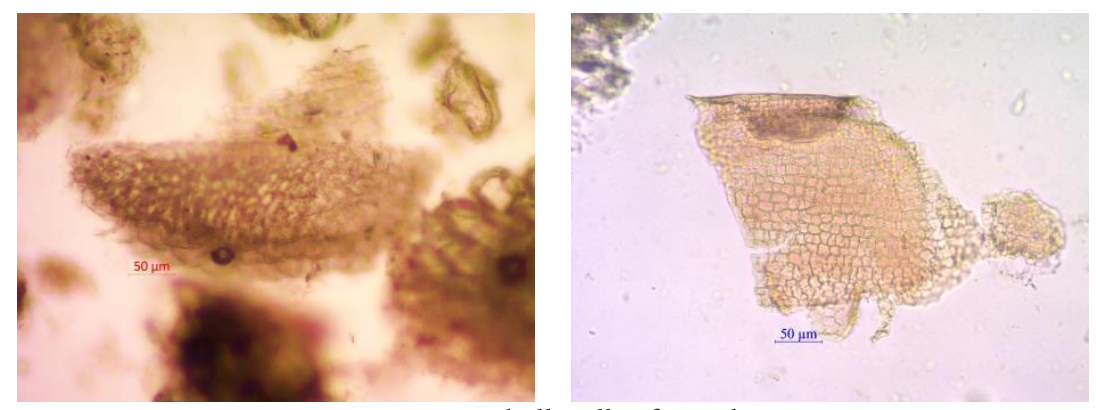

5.6 Mesophyll cells of sepal

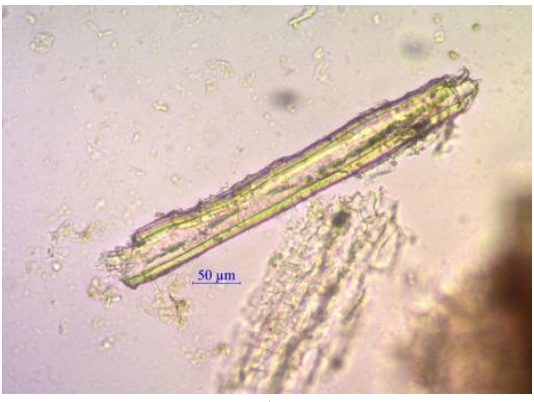

5.8 Fibres

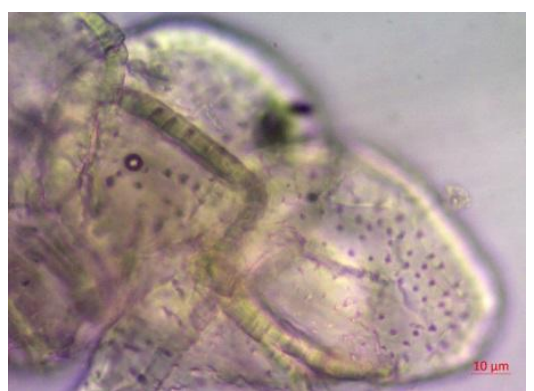

5.10 Stone cells

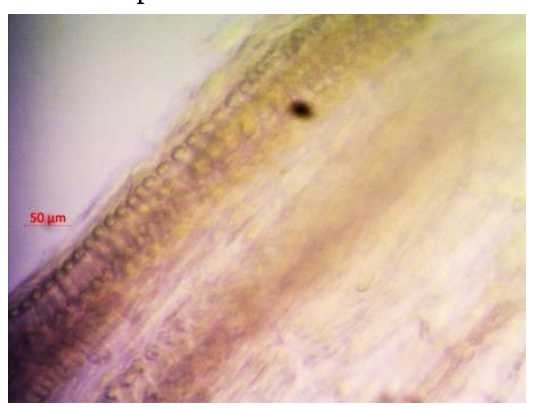

5.9 Vessels

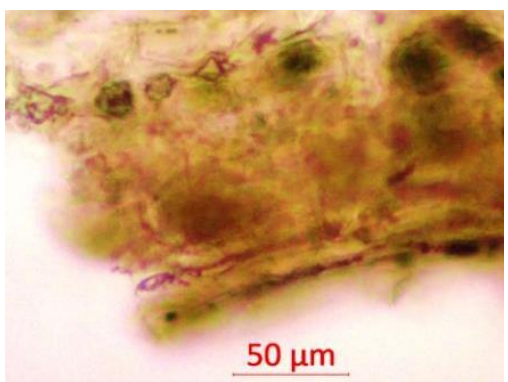

5.11 Cells with rosette crystals

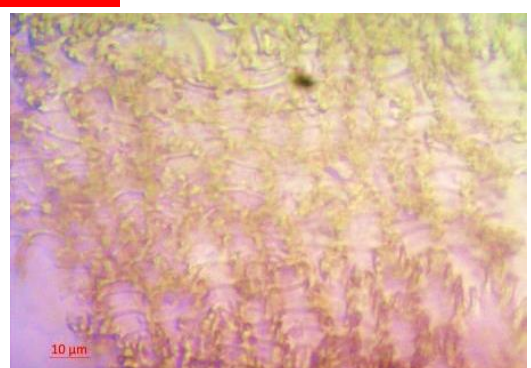

5.3 Epidermal cells with wavy walls

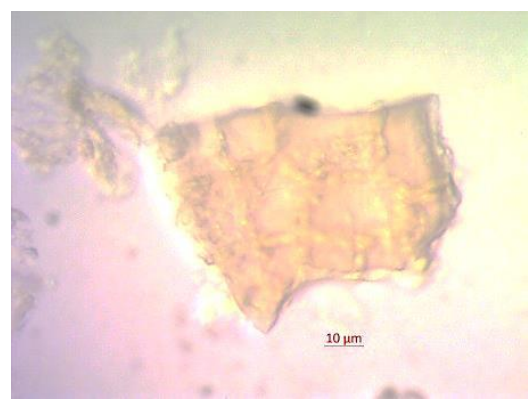

5.5 Thick walled parenchyma

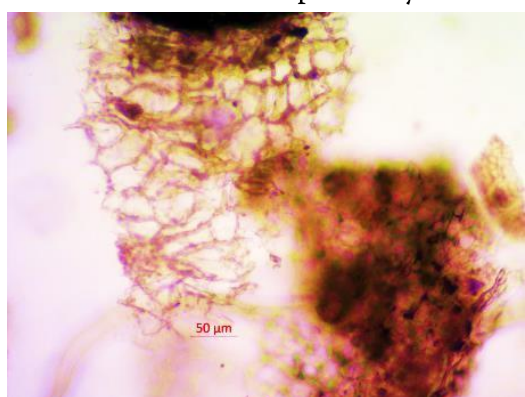

5.7 Thin walled parenchyma
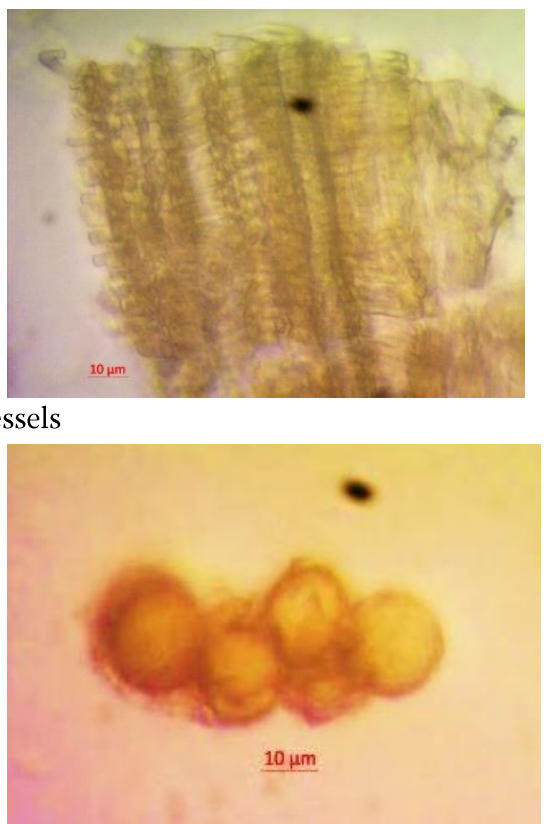

5.12 Pollen grains 
Acknowledgement Authors are grateful to Director General, CCRS, Chennai for the support and Dr. M Padma Sorna Subramanian, Research Officer, Siddha Medicinal Plants Garden, Mettur for proving the samples.

\section{Source of support Nil}

Conflict of interest Authors declare no conflict of interest

Contributors Dr. KG Divya contributed to the conceptualization of the topic, intellectual content and design, Ms. Rubeena helped in data acquisition and literature study, Ms. Remya Andalil carried out the morphological work, Ms. Erni did the microscopy work, Ms. Brindha carried out the powder microscopy. Dr. KN Sunil Kumar edited the manuscript and provided the suitable suggestions, Dr. Sathyarajeshwaran Parameswaran provided the Siddha aspects of the drug.

\section{Reference}

1. Kumari A, Dora J, Anil K, Kumar A. Pomegranate (Punica granatum) Overview. International Journal of Pharmaceutical and Chemical Sciences 2012:1(4):1218-22.

2. Holland D, Hatib K, Bar-Ya'akov I. Pomegranate: Botany, horticulture, breeding. Hort Rev Amer Soc Hort Sci 2009;35:127-91.

3. Lansky EP, Newman RA. Punica granatum (Pomegranate) and its potential for prevention and treatment of inflammation and Cancer. J Ethnopharmacol 2007;109:177-206

4. Ahmad I, Mehmood Z, Mohammad F. Screening of some Indian medicinal plants for their antimicrobial properties. Journal of Ethnopharmacology 1998;62:183-93.

5. Nadkarni AK, Nadkarnis M. Indian Materia Medica, 3rd ed. Mumbai, India: Popular Prakashan Private Limited, 2000: Vol. I, p.1031-5.

6. Warrier PK, Nambiar VPK, Ramankutty C. Indian Medicinal Plants a compendium of 500 species. Hyderabad, India: Orient Longman Private Limited, Hyderabad, 2002:Vol.4, p.396-402.

7. Blatter E, Cains JF, Mhaskar KS. Indian Medicinal Plants 2nd ed. Uttranchal, India: Oriental Enterprises, 2001: p.1506-13
8. Prashanth D, Asha MK, Amit A. Antibacterial activity of Punica granatum. Fitoterapia 2001;2:171-3.

9. Chatterjee A, Pakrashi SC. The treaties of Indian Medicinal Plants. New Delhi: CSIR, 1991; p.190-2.

10. Hussain A, Virmani OP, Popli SP. Dictionary of Indian Medicinal Plants. Lucknow, India: CIMAP, 1992: p.384.

11. Pirbalouti AG, Koohpayeh A, Karimi I. The wound healing activity of flower extracts of Punica granatum and Achilleakallalensis in Wistar rats. Acta Poloniae Pharmaceutica and Drug Research 2010;67:107-10.

12. Jurenka JMT. Therapeutic Applications of Pomegranate (Punica granatum L.): A Review. Alternative Medicine Review 2008;13:12844.

13. Anonymous. Siddha Formulary of India, Part I. New Delhi: Ministry of family Health and welfare, 1992; p.90-1.

14. Divya KG, Remya A, Brindha S, Sunil Kumar KN, Sathiyarajeshwaran P. Comparative macro-microscopic atlas of two aroids used in Siddha medicine. J Ayu Med Sci 2017;2(4):256-60.

15. Graham SA, Graham A. Ovary, fruit and seed morphology of the Lythraceae. Int J Plant Sci2014;175:202-40.

16. Berger BA, Kriebel R, Spalink D, Sytsma KJ. Divergence times, historical biogeography, and shifts in speciation rates of Myrtales. Mol Phylogen Evol 2016;95:116-36.

17. Byng JW, Chase MW, Christenhusz MJM, Fay MF, Judd WS, Mabberley DJ, Sennikov AN, et al. An update of the angiosperm phylogeny group classification for the orders and families of flowering plants: APG IV. Bot J Linn Soc 2016;181:1-20.

18. Chaudhari SM, Desai UT. Effects of plant growth regulators on flower sex in pomegranate (Punica granatum L.). Indian J AgrSci 1993;63:34-5.

19. Herlihy CR, Eckert CG. Genetic cost of reproductive assurance in a self-fertilizing plant. Nature 2002;416:320-3.

20. Tanurdzic M, Banks JA. Sex-determining mechanisms in land plants. Plant Cell 2004;16:61-71.

21. Bertin RI. The evolution and maintenance of andromonoecy. Evol Theory 1982;6:25-32.

22. Meera Devi, SP, Arulvasu C, Ilavarasan R. Morphological and anatomical studies on ornamental flowers of Punica granatum Linn. Journal of Pharmaceutical and Scientific innovation 2015;4(1):44-51. 